Kinestetik : Jurnal Ilmiah Pendidikan Jasmani 5 (2) (2021)

Kinestetik : Jurnal Ilmiah Pendidikan Jasmani

https://ejournal.unib.ac.id/index.php/kinestetik/index

DOI : 10.33369/jk.v5i2.14098

\title{
IMPLEMENTATION OF PHYSICAL FITNESS VISUAL BOARD TO ESTABLISH COMMUNITY PHYSICAL FITNESS LEVEL IN BATU LICIN COASTAL SOUTH KALIMANTAN
}

\author{
Edwin Wahyu Dirgantoro*1, Lazuardy Akbar Fauzan ${ }^{2}$ \\ ${ }^{12}$ Department of Sports and Health Education, Universitas Lambung Mangkurat
}

\section{Article Info \\ Article History : \\ Received : January 2021 \\ Revised : March 2021 \\ Accepted : June 2021 \\ Available online : June 2021}

Keywords:

Physical Fitness, Comunity, Coast

\begin{abstract}
The coastal area is a space for humans to do activities. The area is a place for the community to carry out various sports and other physical activities. Every sport activity carried out regularly will affect the level of physical fitness. This study aims to determine the acceptance response of the physical fitness visual board and the effectiveness of the physical fitness visual board to determine the physical fitness level of the community. This research is a quantitative descriptive. The sample in this study was Batulicin coastal community as many as 50 people. In collecting data in this study, a survey method with test techniques was conducted. To determine the fitness level, the test used was the $2.4 \mathrm{~km}$ running test. To find out the public response to the use of physical fitness visual boards, questionnaires were distributed. The results of this study showed that the body mass index (BMI) was included in the ideal body category of 58\%, the category of body fat was $16 \%$, and the category of the thin body was $26 \%$. The levels of physical fitness of the coastal community are $40 \%$ in good category, $40 \%$ in acceptable category, $16 \%$ in poor category, $2 \%$ for each very good category and very poor category. The acceptance response to the physical fitness visual board is in the very good category. A sample as much as $94 \%$ said it was very good. The effectiveness of using the physical fitness visual board to determine the level of physical fitness of the community is in the very good category. A sample of $94 \%$ stated very well.
\end{abstract}

\footnotetext{
Corresponding address : Jl. Brigjen H. Hasan Basri, Pangeran, Kec.

ISSN 2685-6514 (Online)

Banjarmasin Utara, Kota Banjarmasin, Kalimantan Selatan

ISSN 2477-331X (Print)

*Corresponding email : edwin.dirgantoro@ulm.ac.id
} 


\section{INTRODUCTION}

Fitness and health are important aspects (Sukamti, 2016). To carry out daily activities, everyone must have a good level of body fitness, so that they can carry out activities without experiencing fatigue. Physical fitness is the condition or ability of a person to carry out activities or daily activities easily without experiencing significant fatigue and still has spare time to enjoy his time for other purposes. So that healthy people can enjoy life, both physically, mentally, emotionally and socially (total fitness). Physical fitness is the quality for someone to do activities suit the job optimally without causing health problems and excessive fatigue (Edo Prasetio, Ari Sutisyana, 2017)

Someone can think and have good performance if they have a fit physical fitness, because with good physical fitness a person will not tire easily (F. Abdurrahim, 2018). With the knowledge of the level of fitness that is known by the community, it will be easier for the community and it is hoped that it can motivate people to play an active role in improving physical fitness through sport activities. Physical fitness is closely related to society, namely physical fitness related to health. This needs to be considered by the community because it will affect the level of public health.

Physical fame can be increased through community participation in sports. There are three factors that influence people's participation in sports, namely individual factors, environmental factors, and socio-cultural factors (Yudik Prasetyo, 2013). Environmental factors influence the choice of sports or physical activities carried out by the community.

Through this research, the researcher conveyed to the public about a physical fitness visual board that could be directly observed so that people could immediately find out the nutritional status through the measurement of the Body Mass Index and the level of their physical fitness.

The objectives of this study are (1) How the public acceptance response through the use of physical fitness visual boards to determine the level of physical fitness in Batu Licin coastal communities is, (2) How effective the use of physical fitness visual boards to determine the level of physical fitness in Batu Licin coastal communities is.

\section{Physical Fitness}

Physical freshness is a person's physical ability to carry out his daily duties effectively and efficiently in a relatively long time without experiencing fatigue (Fauzan, 2020). Fitness is classified into two categories, namely: health-related fitness or skill-related fitness (Hoeger, Werner, 1996). According to the (Departemen Keseharan RI, 2009), Health Related Fitness is physical fitness related to cardiovascular endurance, muscle strength, flexibility, and body composition. In detail Health Related Fitness can be described as the following:

a. Cardiorespiratory Endurance.

- The most important component in the assessment of physical fitness status or someone's stamina. 
- The amount of cardiovascular endurance is measured by assessing the volume maximum oxygen that can be used by the body (VO2 max).

b. Muscle Strength and Endurance.

- The muscle's ability to perform repeated contractions against a submaximal and maximal load within a certain period of time.

- The ability to overcome fatigue and decreased muscle strength will disrupt the balance of the body and the risk of falling.

\section{c. Flexibility}

- The joint's ability to perform movements in the maximum joint space.

- The freedom of body movement in the joints is greatly influenced by the elasticity of the muscles, tendons and ligaments around the joints and the joints themselves.

- Affects one's posture, eases body movement, reduces stiffness, increases skill, and reduces the injury risk.

d. Body Composition.

Consists of lean body mass and body fat. The parameters consist of: (1) Body mass index is the weight measured in one kilogram divided by the height in square meters describing the proportion of body weight to height, (2) Measurement of waist circumference. Factors Affecting Physical Fitness can be influenced by: (1) age, (2) gender, (3) heredity, (4) diet, (5) smoking habit (6) exercise.

\section{Body Mass Index}

Body Mass Index is one way to determine nutritional status by comparing body weight and height (Departemen
Keseharan RI, 2009). Body Mass Index (BMI) can be used to assess the nutritional status or determine the standard proportion of body composition in adults, adolescents to children (Gibson, 2005). BMI has a good correlation value and is easy to determine nutritional status so that it can be widely used and accepted as an indicator to diagnose nutritional status (Retno Ayu Widyastuti, 2018).

I Dewa Nyoman Supariasa in (Adawiyah, 2016), explained that the Body Mass Index (BMI) is a simple tool to monitor nutritional status, especially those related to excess and underweight. (Sulistianingrum, 2010) states that IMT has various advantages, namely: 1) The equipment used for IMT measurements is economical and easy to obtain so that the costs incurred are relatively small. 2) Measurement of BMI is easy and does not require special skills, only requires measurement accuracy. 3) BMI measurement is safe and non-invasive. Based on the BMI measurement method in WHO 2011 to determine the body mass index of a person, the sample is first measured with a weight and then the height is measured and entered into the formula below:

$$
\mathrm{IMT}=\frac{\text { Weight }(\text { kilogram })}{\text { Height } \times \text { Height }(\text { meter })}
$$

\section{Physical Fitness Visual Board}

The physical fitness visual board is a medium to help people know their fitness norms. Media is a determining factor in the public system (R. Sunardianta, Amat Komari, 2015). Because through the media the process of delivering information will be created. Without the media, information delivery will not be conveyed. This media 
contains information related to nutritional status through the measurement of Body Mass Index and norms of physical fitness levels using running and walking tests under the definition of physical fitness related to health according to the Indonesian Ministry of Health.

\section{METHODS}

This research is a quantitative descriptive. According to (Sugiyono, 2016), quantitative research methods are based on the philosophy of positivism, used to research on a particular population or sample, sampling techniques are generally carried out randomly, data collection uses research instruments, data analysis is quantitative / statistics. This study uses a descriptive approach to describe the object of research or research results. Descriptive, according to (Sugiyono, 2016), is a method that describes or give an overview of the object under study through data or samples that have been collected as it is, without conducting analysis and making general conclusions.

\section{Sampling Procedures}

The sample in this study was the Batulicin coastal community as many as 50 people. Subject criteria are 1) men and women aged 15-60 years, and 2) domiciled in the Batulicin area, 3) social status from students to those who are still working. The data collection technique used is random sampling. The research period was conducted for 2 months, starting from August to September 2020.
Materials and Apparatus

According to (Arikunto, 2016), data collection instruments are tools that are selected and used by researchers in collecting data so that these activities become systematic and made easier by them. According to (Sugiyono, 2016), the questionnaire is a data collection technique that is done by giving a set of questions or written statements to the sample to be answered. The questionnaire used in this study is a closed questionnaire, which is a questionnaire that presents questions and answers choices so that the sample can only provide limited responses to the choices given. The instruments or tools used in this research are in the form of a questionnaire. The instrument for data collection is filling out a questionnaire done by the sample to determine the public's response to the usefulness of the physical fitness visual board. Next, filling in the list of physical fitness values is to determine the level of physical fitness of Batu Licin community.

Procedures

In collecting data in this study, a survey method with test techniques was used. To obtain research data, the authors collected data using the following techniques:

1. Observation

Field observation techniques are carried out to obtain actual and direct data by systematically observing and recording the symptoms or phenomena that exist in the object of research. Besides, field observations were carried out to observe the location, both the physical condition 
and the condition of the community in the research area by going directly to the field. This technique is used to observe directly community activities in the field.

2. Test

The test used is a cardiovascular test by running as far as $2.4 \mathrm{~km}$. To determine the body's category, the authors used the Body Mass Index (BMI).

3. Questionnaire

Questionnaires are used to measure the response from the community. This is done by submitting a questionnaire sheet containing a list of questions to the sample. The list of questions is closed, which means that alternative answers have been provided, unless the list of questions regarding the identity of the sample is open. The questionnaire used is an attitude scale test that refers to the Likert scale parameter. The answer choices are categorized as a statement of the attitude of SB (very good), B (good), C (sufficient), K (Poor), and SK (very poor). This questionnaire is given after all stages of the test implementation have been completed.

Design or Data Analysis

Data analysis used in this study used a Likert scale to measure attitudes, opinions, and perceptions of a person or group of people about the phenomenon. In this study, the Likert scale was used to measure the community's response to the use of the physical fitness visula board. A trend will be obtained for the sample answers. The questionnaires distributed were conducted using a Likert scale. Then the sample answer index calculation is done with the following formula:

Index Value $=((\mathrm{F} 1 \mathrm{x} 1)+(\mathrm{F} 2 \mathrm{x} 2)+(\mathrm{F} 3 \mathrm{x} 3)$

$+(\mathrm{F} 4 \mathrm{x} 4)+(\mathrm{F} 5 \mathrm{x} 5) / 5$

Score Interpretation Criteria:

Point $0 \%-20 \%=$ Very Poor

Point $21 \%-40 \%=$ Poor

Point $41 \%-60 \%=$ Sufficient

Point $61 \%-80 \%=$ Good

Point $81 \%-100 \%=$ Very Good

Quantitative analysis techniques were used to manage and interpret numerical or systematic data. This type of analysis used percentage analysis using a formula:

$$
\mathrm{P}=\frac{f}{n} \times 100 \%
$$

Note :

$\mathrm{P}:$ the percentage sought $(\%)$

$\mathrm{f}$ : the number of samples who chose alternative answers

$\mathrm{N}$ : the total number of samples

The numbers entered into the percentage formula above were the data obtained from the sample answers to the questions posed. The calculation results were then compared with the predetermined criteria.

\section{RESULT}

1. The community acceptance response to the use of physical fitness visual boards

$$
\text { Researchers distributed }
$$

questionnaires to the sample to determine the Acceptance Response using a physical fitness visual board. After the sample filled out the questionnaire, the following data were obtained: 
Table 1. Frequency Distribution of Public Acceptance Responses to the Use of Physical Fitness Visual Board

\begin{tabular}{|c|l|c|c|c|}
\hline No. & \multicolumn{1}{|c|}{ Interval } & Frequency & Percentage & Category \\
\hline 1 & $61<\mathrm{X}$ & 48 & $84 \%$ & $\begin{array}{c}\text { Strongly } \\
\text { Agree }\end{array}$ \\
\hline 2 & $60<\mathrm{X}<46$ & 8 & $16 \%$ & Agree \\
\hline 3 & $45<\mathrm{X}<31$ & 0 & $0 \%$ & $\begin{array}{c}\text { Fairly } \\
\text { Agree }\end{array}$ \\
\hline 4 & $30<\mathrm{X}<16$ & 0 & $0 \%$ & Disagree \\
\hline 5 & $\mathrm{X}<15$ & 0 & $0 \%$ & $\begin{array}{c}\text { Strongly } \\
\text { Disagree }\end{array}$ \\
\hline
\end{tabular}

Based on the table above, it was found that 42 people $(84 \%)$ were in the "strongly agree"category and 8 people $(16 \%)$ had responses in the "agree" category.

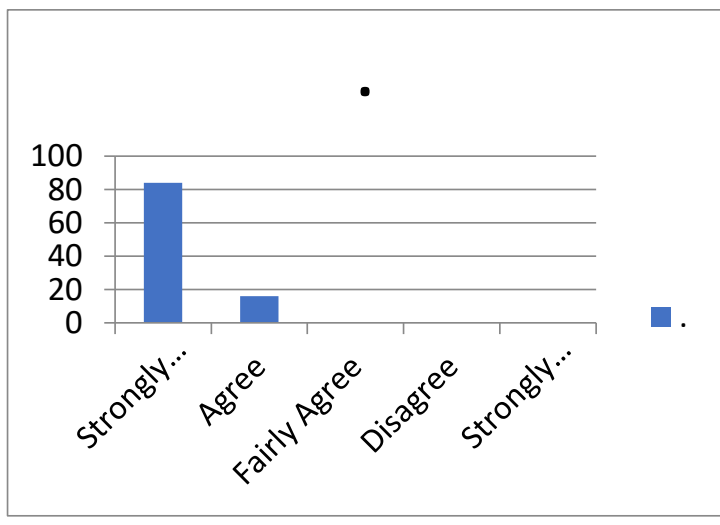

Figure 1. Bar diagram of the community's response to the implementation of the physical fitness visual board

2. The effectiveness of using the physical fitness visual board

The researcher distributed a questionnaire to the sample to determine the effectiveness of using a physical fitness visual board to analyze the physical fitness level of the community. After filling out the questionnaire, the following data were obtained:
Table 2. Frequency distribution of public acceptance responses to the use of physical fitness visual boards

\begin{tabular}{|c|l|c|c|c|}
\hline No. & Interval & Frequency & Percentage & Category \\
\hline 1 & $25<\mathrm{X}$ & 41 & $82 \%$ & $\begin{array}{c}\text { Strongly } \\
\text { Agree }\end{array}$ \\
\hline 2 & $19<\mathrm{X}<24$ & 9 & $18 \%$ & Agree \\
\hline 3 & $13<\mathrm{X}<18$ & 0 & $0 \%$ & $\begin{array}{c}\text { Fairly } \\
\text { Agree }\end{array}$ \\
\hline 4 & $7<\mathrm{X}<12$ & 0 & $0 \%$ & Disagree \\
\hline 5 & $\mathrm{X}<6$ & 0 & $0 \%$ & $\begin{array}{c}\text { Strongly } \\
\text { Disagree }\end{array}$ \\
\hline
\end{tabular}

Based on the table above, it is found that 41 people $(81 \%)$ were in the "strongly agree" category and 9 people $(18 \%)$ were in "agree" category. Thus, when viewed from the frequency diagram for each category, it will be seen as follows:

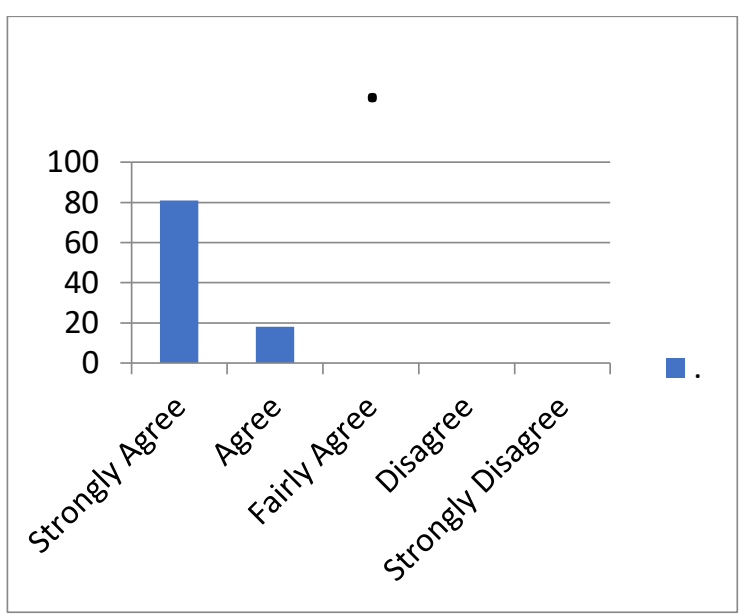

Figure 2. Bar diagram of the community's response to the implementation of the physical fitness visual board

3. Community physical fitness level (health related fitness)

\section{A. Body Composition}

The results of research that have been carried out based on the Body Mass Index (BMI) of the Batulicin coastal community were as follows: 
Tabel 3. The body composition of the Batulicin coastal community

\begin{tabular}{|c|c|c|c|c|c|}
\hline Status & $\begin{array}{c}\text { Very } \\
\text { Thin }\end{array}$ & Thin & Ideal & Fat & Obese \\
\hline $\mathrm{N}$ & 1 & 2 & 3 & 4 & 5 \\
\hline Frequency & 0 & 13 & 29 & 8 & 0 \\
\hline Percentage & $0 \%$ & $26 \%$ & $58 \%$ & $16 \%$ & $0 \%$ \\
\hline
\end{tabular}

Based on the table above, it can be concluded that based on the body mass index (BMI) of coastal communities as much as $58 \%$ is in the ideal body category, $16 \%$ is in the fat category, and $26 \%$ is in the thin body category.

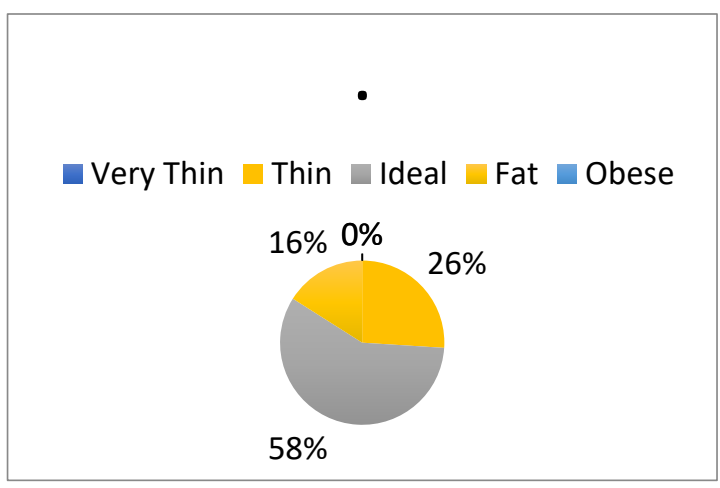

Figure 3. Diagram of the Body Mass Index (BMI) of the Batulicin coastal community

\section{B. Level of Physical Fitness}

The results of measuring the fitness level of the Batulicin coastal community using a cardiovascular endurance test with a $2.4 \mathrm{~km}$ running test were as follows:

Table 4. The level of physical fitness of the Batulicin coastal community

\begin{tabular}{|c|c|c|c|c|c|}
\hline Status & $\begin{array}{c}\text { Very } \\
\text { Poor }\end{array}$ & Poor & Moderate & Good & $\begin{array}{c}\text { Very } \\
\text { Good }\end{array}$ \\
\hline $\mathrm{N}$ & 1 & 2 & 3 & 4 & 5 \\
\hline Frequency & 1 & 8 & 20 & 20 & 1 \\
\hline Percentage & $2 \%$ & $16 \%$ & $40 \%$ & $40 \%$ & $2 \%$ \\
\hline
\end{tabular}

Based on the table above, it can be concluded that the level of physical fitness of coastal communities as much as $2 \%$ is in the "very poor" category, $16 \%$ is in the "Poor" category, $40 \%$ is in the "moderate" category, as many as $40 \%$ is in the "good" category and $2 \%$ is in the category "very good" category.

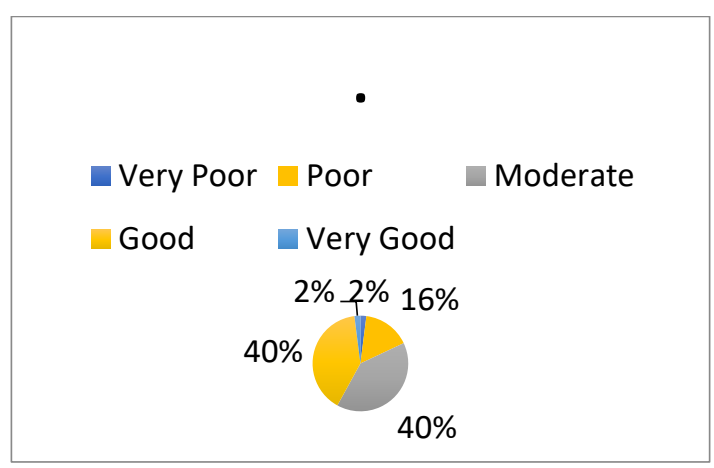

Figure 4. Diagram of the physical fitness level of the Batulicin coastal community

\section{DISCUSSION}

This study was to determine the public's response to the physical fitness visual board which was used to find out the physical fitness level of the community. The sample first performed a body mass index (BMI) test and a cardiovascular endurance test with a 2.4 $\mathrm{km}$ running test. After conducting the test, the sample could immediately confirm the results obtained in the form of summary information on the physical fitness visual board. Body mass index (BMI) was included in the ideal body category of $58 \%$, in the category of fat body $16 \%$, and in the category of thin body $26 \%$. The physical fitness level of the coastal community was $40 \%$ in the good category, $40 \%$ in the moderate category, $16 \%$ in the poor category, $2 \%$ in both the very good category and the very poor category. 
These results should be of concern considering that physical activity, body mass index, and body fitness are closely related. Research shows that the higher a person's physical activity, the more likely he is to have a good cardiovascular fitness (ACSM's, 2010). Cardiovascular fitness is arguably the most important component to health. Some of the benefits for health are as follows (Corbin CB, Welk GJ, Corbin WR, 2009): 1) Good cardiovascular fitness reduces the risk of heart disease, premature death, and various chronic degenerative diseases. 2) Cardiovascular fitness is a independent risk factor of other risk factors., 3) Good cardiovascular fitness increases the ability to work and do daily activities. The next sample responded to the use of a physical fitness visual board. The acceptance response to the physical fitness visual board was in the very good category. $94 \%$ of the samples said it was very good. The effectiveness of using the physical fitness visual board to determine the level of physical fitness of the community was very good. A sample of $94 \%$ stated very well.

When associated with the opinion of (Mudlofir, 2016) states that media in printed and non-printed form is an intermediary from sender to recipient so that the recipient has motivation to improve their abilities. Furthermore, it is expected to obtain more satisfying learning outcomes. The media used must be attractive, so that people can be motivated to use it. The physical fitness visual board media has the advantage that it can be easily used as a source of information about the status of the body's criteria and the level of physical fitness a person has.

\section{CONCLUSION}

The results showed that the majority of the body mass index (BMI) of the Batulicin coastal community was in the ideal body category. Cardiovascular fitness level is in good category. The public response and the effectiveness of using physical fitness visual boards is very good. People can maintain their fitness level through routine physical activity and using physical fitness visual boards to determine their physical fitness level.

\section{ACKNOWLEDGEMENT}

We would like to thank the Chancellor of Lambung Mangkurat University and LPPM Leaders who have supported our research in the form of funding so that this journal can be published.

\section{REFERENCES}

ACSM's. (2010). Resource Manual for Guidelines for Exercise Testing and Prescription (6th ed).

Adawiyah, N. R. Al. (2016). Hubungan Antara Status Gizi dengan Tingkat Aktivitas Jasmani Siswa Kelas V Mi Darul Hikmah [Universitas Negeri Yogyakarta]. https://eprints.uny.ac.id/41708/

Arikunto, S. (2016). Manajemen Penelitian. PT. Rineka Cipta.

Corbin CB, Welk GJ, Corbin WR, W. K. (2009). Concepts of Fitness and Wellness: a Comprehensive Lifestyle Apporach. McGraw-Hill.

Departemen Keseharan RI. (2009). Departemen Keseharan RI. (2009). Diambil 
http://www.depkes.go.id/index.php?txt Keyword=status+gizi\&act=search-bymap\&pgnumber $=0 \&$ charinde $x=\&$ struci $\mathrm{d}=1280 \&$ fullcontent $=1 \& \mathrm{C}-\mathrm{ALL}=1$,

Pada tanggal 21 September 2020.

Edo Prasetio, Ari Sutisyana, dan B. R. I. (2017). Tingkat Kebugaran Jasmani Berdasarkan Indeks Massa Tubuh Pada Siswa Smp Negeri 29 Bengkulu Utara. KINESTETIK : Jurnal Ilmiah Pendidikan Jasmani, 1, 86-97.

F. Abdurrahim, I. H. (2018). Tingkat Kebugaran Jasmani Siswa SDNTulungrejo 03 Daerah Dataran Tinggi Kecamatan Bumiaji Kota Batu Tahun Pelajaran 2018/2019. Indonesia Performance Journal, 2, 68-73.

Fauzan, L. A. dan D. (2020). Profil Kebugaran Jasmani Atlet Pencak Silat Pplp Kalimantan Selatan. Riyadhoh Jurnal. UPT Publikasi Dan Pengelolaan Jurnal. Universitas Islam Kalimantan Muhammad Arsyad Al-Banjari Banjarmasin, Vol 3 Nomo, 80-86. https://ojs.uniska-

bjm.ac.id/index.php/riyadhohjurnal/issu e/view/388

Mudlofir, A. dkk. (2016). Desain Pembelajaran Inovatif Dari Teori Ke Praktik (Rajawali Pers (ed.)).

R. Sunardianta, Amat Komari, H. A. (2015). Pergeseran Fungsi Olahraga Dalam Dimensi Sosial (Sebuah kajian Kritis Sosiologis Atas Fenomena Olahraga Kekinian). Universitas Negeri Yogyakarta.

Retno Ayu Widyastuti, A. R. (2018). Indeks Massa Tubuh Menurut Umur sebagai Indikator Persen Lemak Tubuh pada Remaja. Jurnal Unimus, 32-39.

Sugiyono. (2016). Metode Penelitian Kuantitatif, Kualitatif dan $\mathrm{R}$ \&D. Alfabeta.

Sukamti, E. R. (2016). Profil Kebugaran Jasmani Dan Status Kesehatan Instruktur Senam Aerobik Di Yogyakarta. Jurnal Olahraga Prestasi, Volume 12, 31-40. https://journal.uny.ac.id/index.php/jorpr es/article/view/11875/8488

Sulistianingrum, N. D. (2010). Hubungan Indeks Massa Tubuh Dan Rasio Lingkar Pinggang Pinggul Dengan Kadar Gula
Darah Puasa. Universitas Sebelas Maret Surakarta.

Yudik Prasetyo. (2013). Kesadaran Masyarakat Berolahraga Untuk Peningkatan Kesehatan dan Pembangunan Nasional. Jurnal Medikora, XI. No.2, 219-228. 